\title{
PERANCANGAN SISTEM INFORMASI INVENTORY PADA TOKO ROSADAH
}

\author{
Hisbikal Haqqi Muflihin ${ }^{1}$, Harry Dhika ${ }^{2}$, Santy Handayani ${ }^{3}$ \\ Universitas Indraprasta PGRI ${ }^{123}$ \\ Hisbikalhaqiqi32@gmail.com ${ }^{1}$, dhikatr@yahoo.com², santyhandayani1@gmail.com³
}

\begin{abstract}
Abstrak - Sistem informasi inventory merupakan sebuah hal keharusan yang harus dimiliki sebuah perusahaan ataupun usaha yang bergerak pada bidang penjualan dan pembelian agar dapat mengolah data transaksi yang berkaitan dengan persedian dapat dilakukan secara efektif dan efisien, diketahui pelaksanaan sistem inventory di Toko Rosadah masih menggunakan sistem pengolahan data secara manual seperti lamanya mencari data penjualan produk, data pembelian produk maupun pencarian stok produk yang sudah habis atau yang akan habis, retur pembelian produk tidak terkontrol dan juga sering terjadinya kesalahan proses pembuatan laporan dalam perhitungan dan persediaan stok produk yang masih kurang efektif maupun metode pembayaran yang masih menggunakan nota tulis. Untuk dapat mengolah data transaksi yang jumlah cukup banyak diperlukan alat khusus untuk dapat menanganinya oleh sebab itu komputer lah yang menjadi pilihan yang tepat dari berbagai sisi. Dari sisi kecepatan, ketelitian dan keakuratan yang dimilikinya dengan bantuan piranti lunak yang mendukungnya oleh karena itu dibangunlah sebuah sistem informasi inventory dengan menggunakan metode pengembangan sistem air terjun atau yang biasa disebut dengan Waterfall yang melalui beberapa proses tahapan yaitu: requirement, design, implements, verification dan maintenance. Hasil dari penelitian ini ialah membangun sebuah aplikasi yang mampu membantu proses transaksi lebih mudah dan efisien yang dapat membantu pihak toko dalam melakukan kegiatan usahanya.

Kata Kunci : Perancangan, Sistem, Inventory, Grounded Research
\end{abstract}

Abstract - An inventory information system is a must have for a company or business that is engaged in sales and purchases in order to process transaction data related to inventory that can be done effectively and efficiently, it is known that the implementation of the inventory system at Rosadah Store still uses a data processing system. manuals such as the length of time searching for product sales data, product purchase data and product stock searches that have run out or are about to run out, product purchase returns are not controlled and also frequent errors in the reporting process in calculations and product stock inventory are still ineffective and payment methods are still using written notes. To be able to process a large number of transaction data, special tools are needed to handle it, therefore computers are the right choice from various sides. In terms of speed, accuracy and accuracy with the help of software that supports it, therefore an inventory information system was built using the waterfall system development method or commonly called Waterfall which goes through several stages, namely: requirements, design, implements, verification and maintenance. The result of this research is to build an application that is able to help the transaction process easier and more efficiently which can assist the store in carrying out its business activities

Keywords: Planning, Systems, Inventory, Grounded Research

\section{PENDAHULUAN}

Melihat perkembangan teknologi dan ilmu pengetahuan teknologi saat ini, dirasakan sudah semakin maju dan berkembang dengan pesat terbukti dengan manusia tidak bisa terlepas dengan teknologi yang ada saat ini. Pada era persaingan dagang bebas saat ini dibutuhkan pemrosesan data yang lebih cepat, tepat dan akurat. Banyak data ataupun informasi yang perlu diolah tidak dapat memungkinkan untuk menggunakan cara-cara yang manual untuk mengelolanya.

Dalam mengolah data yang jumlah cukup banyak diperlukan alat khusus untuk dapat menanganinya oleh sebab itu komputer lah yang menjadi pilihan yang tepat dari berbagai sisi, dari sisi kecepatan, ketelitian dan keakuratan yang dimilikinya dengan bantuan piranti lunak yang mendukungnya. Penggunaan komputer sebagai perangkat kerja yang berguna untuk pengolahan suatu informasi dalam dunia usaha merupakan suatu hal yang harus dilakukan oleh para pelaku bisnis untuk menjalankan bisnisnya, hal ini sebagai salah satu strategi untuk meningkatkan aktifitas dalam bertransaksi. Penggunaan komputer dan penguasaan keterampilan pengguna software yang terintegrasi dalam proses pengolahan data menjadi suatu bentuk informasi akan dapat dilakukan dengan mudah, cepat dan akurat (Wahana \& Riswaya, 2014).

Diketahui pelaksanaan sistem Inventory di Toko Rosadah masih menggunakan sistem yang bersifat manual seperti lamanya mencari data penjualan produk, data pembelian produk maupun pencarian stok produk yang sudah 
habis atau yang akan habis, retur pembelian produk tidak terkontrol dan juga sering terjadinya kesalahan proses pembuatan laporan dalam perhitungan dan persediaan stok produk yang masih kurang efektif maupun metode pembayaran yang masih menggunakan nota tulis.

Dalam pengolahan data membutuhkan ketepatan dan ketelitian dalam proses transaksi yang terjadi dalam suatu usaha. Kebutuhan itu pula yang perlu dipenuhi oleh Toko Rosadah. Agar proses transaksi tersebut berjalan sesuai dengan apa yang diharapkan pemilik usaha seperti informasi stok produk, pembelian produk dan penjualan produk dapat diperoleh setiap saat dan akurat (Nur Laila, 2011). Oleh sebab itu sudah semestinya menggunakan aplikasi untuk mengolah data transaksi untuk menghindari kesalahan-kesalahan yang kemungkinan terjadi dalam menggunakan sistem manual, oleh karena itu diperlukan sebuah aplikasi yang dapat membantu pekerjaan tersebut maka penulis membangun sebuah sistem informasi inventory yang dapat membantu pengolahan data yang terkait dengan pelaksanaan kegiatan persedian produk.

Berdasarkan permasalahan yang sudah diuraikan sebelumnya penulis dapat merumuskan masalah tersebut dengan beberapa rumusan masalah agar dapat mengatasi permasalahan tersebut yaitu: bagaimana merancang sistem pengolahan data pembelian, penjualan, pendataan produk masuk, stok produk dan retur pembelian produk yang terkomputerisasi lalu bagaimana cara mengimplementasikan sebuah program aplikasi dapat meningkatkan efisiensi kerja dalam hal mengolah data dan bagaimana merancang sebuah sistem yang dapat menyimpan data dalam satu sumber penyimpanan yang dapat membuat sebuah sistem informasi untuk dapat menangani proses pelaporan yang tepat dan akurat.

Penelitian ini bertujuan untuk dapat merancang sistem informasi yang digunakan untuk melakukan proses operasional dalam pengolahan data, informasi, transaksi sehingga proses ini tidak lagi dilakukan secara manual membuat penyimpanan data menjadi lebih baik karena sudah tersimpan dengan baik di database melalui program aplikasi sistem informasi yang telah dirancang sehingga dapat meringankan pekerjaan untuk hal pencarian data transaksi hal ini dapat memudahkan dalam proses pekerjaan dalam hal membuat laporan penjualan, laporan pembelian, laporan pemesanan, laporan supplier, laporan stok produk, laporan produk masuk, laporan pelanggan dan laporan retur pembelian selain itu untuk mempercepat proses pencarian data.
Tinjauan Pustaka

Dalam membangun sebuah sistem inventory harus paham apa inventory itu dan memiliki rancangan atau hal-hal yang berkaitan dengan sebuah sistem inventory agar sistem tersebut dapat sesuai dengan hasil yang diharapkan, perancangan itu sendiri adalah gambaran aktivitas-aktifitas dari sebuah proyek akan dibangun dengan menggunakan metode atau teknik khusus untuk menjalankan rancangan tersebut (Arif, 2016).

Setelah rancangan tersebut sudah sesuai dengan yang ingin dicapai maka sistem tersebut dapat dibangun dengan tepat sesuai dengan yang sudah ada dalam perancangan yang sudah dibuat sebelumnya perlu diketahui sistem adalah kumpulan dari beberapa elemen yang saling ketergantungan dan berkaitan untuk mencapai tujuan tertentu yang sudah dirancang sebelumnya (Ardhy, 2017).

Salah satu elemen dari sistem yang paling penting ialah data, data merupakan suatu hal yang belum memiliki sebuah arti bagi penerima dari hal tersebut dan memerlukan suatu kegiatan pengolahan data, data tersebut dapat berupa angka, gambar, suara, huruf maupun abjad (Nugroho, 2018), data tersebut akan diolah menjadi sebuah informasi yang berguna bagi penerima. Informasi itu sendiri merupakan suatu dari kumpulan data, hasil observasi, tanggapan atau kegiatan yang bertujuan untuk menambah pengetahuan menjadi sesuatu yang bermakna dengan maksud dan tujuan pengirim informasi tersebut (Kurniawanto, 2015)

Informasi tidak berasal hanya dari satu data tunggal melainkan hasil dari hubungan dari kumpulan suatu data yang dapat disebut dengan basis data (Wardana, 2018). Agar informasi tersebut dapat dikelola dengan baik maka diperlukan sebuah sistem informasi agar dapat mengolah data tersebut, sistem informasi adalah sistem yang dibuat oleh manusia yang terdiri dari sekumpulan elemen yang menggunakan teknologi komputer dan manual yang dirancang untuk menghimpun, menyimpan dan mengolah data dan serta menghasilkan keluaran yang bermanfaat bagi pemakai sistem tersebut dengan demikian sistem informasi merupakan kombinasi antara prosedur kerja, informasi, user dan teknologi informasi agar dapat mencapai sebuah tujuan dari sistem yang telah dirancang tersebut (Agus Heryanto, Hilmi Fuad, 2014). Untuk menyimpan data tersebut diperlukan sebuah penyimpan basis data salah satu perangkat lunak yang mendukung basis data relational atau hubungan relasi salah satu nya ialah MySQL (My Structure Language), MySQL merupakan DBMS atau Database Management System yang disebarluaskan secara free atau gratis dibawah licence General Public License (GPL) yang setiap orang dapat menggunakannya 
entah untuk komersil ataupun pribadi (Ramadhani et al., 2019).

MySQL menggunakan bahasa SQL (Structure Query Language) yang merupakan inti konsep pengoperasian dari basis data terutama dalam operasi pemilihan, seleksi maupun pemasukan data yang dapat memungkinkan pengoperasian data menjadi lebih mudah dan dilakukan secara otomatis (Agusvianto, 2017). Tujuan utama dari penggunaan basis data ini yang utama ialah isolasi data, dimana data-data tersebut ditempatkan sesuai dengan tempatnya masingmasing lalu yang kedua multi user, saat sebuah organisasi atau perusahaan berorientasi pada suatu masalah maka pihak pertama dapat mendefinisikan masalah tersebut dan kemudian melakukan pengambilan keputusan dari masalah tersebut, untuk mengambil sebuah keputusan tersebut diperlukan sebuah informasi (Rena, 2014).

Dalam bahasan ini berkaitan dengan perancangan aplikasi yang berhubungan dengan inventory, inventory atau persedian ini merupakan sejumlah sumber daya baik yang berbentuk bahan mentah ataupun produk yang sudah jadi yang disediakan oleh perusahaan atau organisasi untuk dapat memenuhi permintaan pelanggan atau konsumen, dapat diartikan juga sebagai pengaturan atau manajemen material yang berkaitan dengan persedian produk (Agus Heryanto, Hilmi Fuad, 2014).

Untuk melakukan perancangan sistem inventory diawali dengan membuat suatu rancangan atau gambaran secara luas agar dapat memahami proses yang sedang berlangsung. Untuk memahami hal tersebut penulis menggambarkan proses tersebut dalam bentuk diagram alir data agar dapat mudah dibaca. Diagram alir data atau Data Flow Diagram merupakan suatu permodelan data secara logika yang menggambarkan darimana data itu berasal dan tujuannya kemana data tersebut mengalir, apa yang diproses, disimpan dimana data tersebut dan interaksi apa yang terjadi ketika data itu diproses dan disimpan (Febriani \& Putra, 2013).

Untuk dapat membaca proses tersebut penulis menggunakan DFD level tertinggi yaitu diagram konteks, diagram konteks adalah diagram yang merupakan level tertinggi dari sebuah diagram alur data (DAD), diagram ini hanya menunjukkan satu proses yang dapat diartikan bahwa proses ini mewakili sistem yang telah dirancang secara keseluruhan (Maniah. \& Hamidin, 2017), untuk mendapatkan basis data sesuai dengan kebutuhan harus mengidentifikasi terlebih dahulu atribut-atribut apa yang harus digunakan pada entitas yang dirancang maka dibuatlah ERD, erd itu sendiri merupakan sebuah teknik dengan cara pendekatan top-bottom dalam merancang sebuah basis data yang diawali dengan mengidentifikasi data yang paling penting yang dapat disebut dengan entitas dan hubungan yang terjalin antara entitas tersebut yang di visualisasikan dengan suatu model (Indrajani, 2011). ERD digunakan untuk memberikan gambaran model struktur data dan hubungan yang terjalin antar data tersebut (Rahmadi \& Yusmiarti, 2016). Setelah ERD sudah ditentukan agar dapat mendapatkan tabel yang maksimal perlu dilakukan normalisasi, normalisasi merupakan sebuah teknik untuk mengidentifikasi hubungan antara entitas satu dengan entitas lainnya dengan menguji hubungan antara entitas dengan pendekatan bottom-up (Indrajani, 2011), normalisasi juga dapat diartikan sebagai suatu proses yang berhubungan dengan model data yang berbentuk relasional untuk dapat mengorganisasikan banyak himpunan data yang saling keterkaitan dan ketergantungan yang erat atau tinggi. Hasil dari proses normalisasi ini ialah himpunan dari tabel-tabel dalam bentuk yang sudah normal (Efendy, 2018).

\section{METODOLOGI PENELITIAN}

A. Metodologi Penelitian

Metodologi adalah suatu ilmu yang membahas tentang metode atau prosedur secara disiplin untuk menata ilmu (Widiawati, 2020). Metodologi disebut juga dengan science of method, yang memiliki arti suatu ilmu yang membahas mengenai langkah-langkah atau petunjuk yang bersifat praktis untuk membahas mengenai konsep suatu teori dengan menggunakan metode-metode (Noor, 2011).

Penelitian adalah suatu metode untuk menyelidiki secara terstruktur atau terorganisir untuk mencari fakta dalam menentukan sesuatu dengan kritis dan hati-hati (Siyoto \& Sodik, 2015). Apabila disatukan metodologi dan penelitian menjadi metodologi penelitian yang memiliki pengertian yaitu sebuah studi atau ilmu yang membahas mengenai metode penelitian yang dapat digunakan sehingga menghasilkan suatu pengetahuan yang baru (Timotius, 2017).

Metode penelitian yang digunakan oleh penulis adalah metode teori bertumpu atau Grounded Research, Metode ini merupakan suatu penelitian didasarkan oleh fakta dan data empiris dengan melakukan analisis perbandingan yang memiliki tujuan untuk penetapan konsep, pembuktian teori dan pengembangan teori dengan mengumpulkan data beserta analisis dilakukuan secara bersamaan (Tarjo, 2019). Agar dapat memudahkan proses membaca alur kerja dalam proses perancangan sisem informasi inventory ini penulis menggunakan diagram arus data.

B. Teknik Pengumpulan Data

Penulis melakukan pengumpulan data 
dengan beberapa metode pengumpulan data yaitu: studi kepustakaan (Library Research) dengan cara dengan mengumpulkan data serta informasi dari kutipan-kutipan buku, beberapa hasil penelitian yang sudah dilakukan dengan memilih topik yang serupa, serta catatan selama di perkuliahan yang terkait dengan pembuatan sistem. Dari bahan-bahan yang dikumpulkan didapat beberapa teori-teori yang mendukung topik ini sebagai bahan untuk menganalisa dan menyelesaikan permasalahan yang sedang diteliti agar dapat mendukung studi kepustakaan tersebut penulis melakukan wawancara dengan dengan pemilik Toko Rosadah ini, yaitu papak Darma untuk mengetahui sistem inventory atau persediaan produk di Toko Rosadah untuk mengetahui kendala-kendala atau masalah yang dapat menghambat proses kegiatan transaksi di toko ini sebagai bahan untuk perancangan aplikasi yang dapat meningkatkan efektifitas transaksi di toko dan penulis agar dapat membantu pengumpulan data, penulis melakukan survey ini untuk mengamati secara langsung bagaimana proses inventory atau persedian di Toko Rosadah yang sedang berjalan dan mengumpulkan data beserta keterangan guna untuk membantu dalam penelitian.

C. Langkah-Langkah Pengembangan Sistem Penelitian ini mengunakan metode penelitian Waterfall. Model waterfall merupakan suatu model pengembangan sistem yang berdasarkan pada daur hidup perangkat lunak yang biasa disebut dengan SDLC (Software Development Life Cycle) yaitu model yang diawali dengan perencanaan analisis desain suatu sistem hingga implementasi sistem tersebut (Yurindra, 2017)

Model SDLC juga dapat diartikan sebagai metode yang memiliki ciri khusus karena pada setiap pengerjaan dilakukan pada setiap fase hingga selesai baru selanjutnya ke fase berikutnya. Dengan demikian hasil akan fokus terhadap pengerjaan pada masing-masing fase sehingga mendapatkan hasil yang maksimal setelah dilakukan pengerjaan pada setiap fase karena tidak ada pengerjaan yang dilakukan secara berulang atau secara parallel (Nugraha et al., 2018).

Fungsi utama metode SDLC ini yaitu mengakomodasi beberapa kebutuhan dalam membangun sistem informasi yang berkaitan dengan dalam membangun sistem informasi, kesiapan pengguna dalam menggunakan sistem yang baru dan kemampuan pengguna dalam mengoperasikan sistem yang baru tersebut (Munthe, 2019). Metode pengembangan sistem waterfall memiliki tahapan atau langkah untuk pengembangan sistem itu sendiri (Marina et al., 2017). Tahapan yang dimaksud ialah:

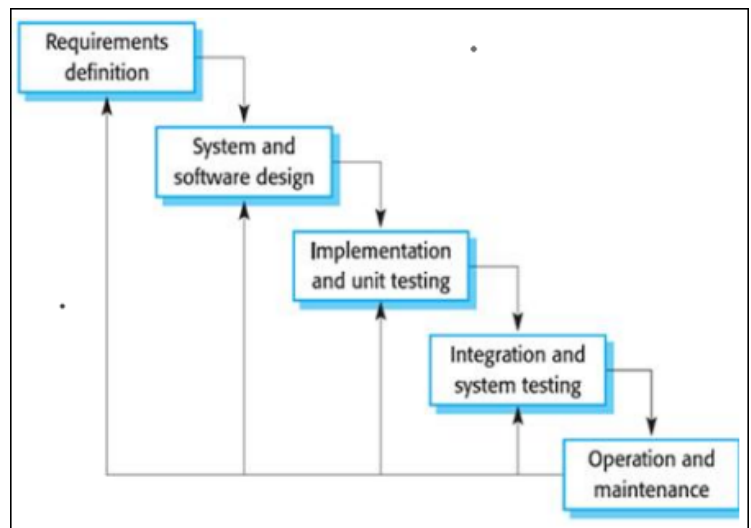

Sumber: (Sasmito, 2017)

Gambar 1. Model Waterfall

Adapun langkah-langkah dalam metode waterfall dalam penelitian ini adalah sebagai berikut:

1. Requirement

Requirement atau analisis merupakan tahapan pada pengembangan sistem yang bertujuan untuk menganalisa sebuah permasalahan dan mencari sebuah solusi dari permasalahan tersebut. Dalam hal analisis yang dilakukan dengan menganalisa data dari hasil analisis yang digunakan pada transaksi inventory atau persedian produk di toko serta prosedur pelaksanaannya.

\section{Design}

Pada tahapan ini memberikan gambaran mengenai proses-proses yang dikerjakan dan bagaimana bentuk tampilannya pada program yang akan dibangun. Agar dapat dipahami oleh pemakai, hasil analisis tersebut dibentuk ke dalam bentuk DFD, ERD, struktur tabel dan rancangan layar dari program yang akan dibangun.

\section{Implements}

Tahapan implements atau implementasi ini dilakukan dengan cara pengkodean untuk mengimplementasikan design dan hasil analisis yang telah dirancang. Untuk hal pembuatan sistem informasi inventory toko Rosadah ini menggunakan program editor Netbeans dan penyimpanan data MySQL serta bahasa pemrograman java.

\section{Verification}

Verification adalah tahap pengujian suatu sistem yang telah dibuat untuk memverifikasi sistem tersebut. Tahap pengujian ini dapat dilakukan dengan memberikan suatu contoh kasus pada setiap modul program pada aplikasi inventory untuk memastikan program tersebut dapat berjalan dengan sesuai yang diharapkan demi menghindari kesalahan sisten atau bug program yang dapat menyebabkan program crash, hank, ataupun kegagalan sistem lainnya yang menyebabkan hasil tidak sesuai yang diharapkan. 


\section{Maintenance}

Tahapan ini dilakukan untuk pemeliharaan sistem apabila sistem yang telah dibuat mengalami pembaruan sesuai dengan permintaan pemakai sistem inventory yang dibuat ataupun perbaikan bug atau kesalahan pada program yang dialami oleh pemakai sistem inventory ini. Hal ini dilaksanakan guna mencapai sistem informasi inventory yang dapat berguna untuk Toko Rosadah ini.

\section{HASIL DAN PEMBAHASAN}

A. Analisa Permasalahan

Diketahui pengolahan informasi inventory produk di Toko Rosadah ini masih menggunakan proses pengolahan data secara manual yang memungkinkan dapat menyebabkan kesalahan dalam proses transaksi. Bagian kasir mengalami kendala ketika dalam melakukan transaksi penjualan, kendala yang dimaksud seperti: perhitungan total belanja masih manual, pembayaran pesanan yang dilakukan ke supplier tidak terkontrol sehingga meningkatkan resiko kerugian pada toko tersebut dan data pembelian dan penjualan sering hilang.

Kendala dialami juga pada bagian Staff Pelayanan, produk yang masuk, produk retur, pemesanan produk masih menggunakan manual sehingga aktifitas transaksi tersebut tidak dapat di pantau atau di kontrol yang dapat menyebabkan stok produk yang ada pada toko tersebut tidak terpantuau. Selain itu dalam proses pembuatan laporan juga harus melihat dan mencari transaksi sebelumnya sehingga dalam proses pembuatan laporan ini memakan waktu yang lama dan tidak efisien dan meningkatkan resiko kesalahan dalam proses pembuatan laporannya yang akan diberikan kepada pemilik toko

B. Alternatif Penyelesaian Masalah

Untuk mencari solusi dari permalahan yang ada maka penulis membuat suatu sistem informasi inventory yang sudah terkomputerisasi digunakan untuk membantu pihak kasir dan staff pelayanan dalam melakukan kegiatan transaksi dan membuat laporan sehingga tidak mengolah data tersebut dengan proses yang manual dan media kertas lagi yang sering terjadi kesalahan selain itu untuk menghindari kesalahan dari faktor manusia atau human error.

Dalam perancangan ini penulis menggunakan satu media penyimpanan data agar dapat memudahkan dalam proses pencarian data-data sehingga dapat menghemat waktu serta meningkatkan efisiensi kerja dan memudahkan dalam membuat laporan-laporan yang diperlukan oleh toko untuk melihat transaksi-transaksi yang sudah dilakukan oleh toko sehingga aktivitas pada toko Rosadah ini dapat terpantau atau terkontrol untuk mengurangi resiko kerugian ataupun kesalahan yang dilakukan manusia atau human error.

C. Desain

Berdasarkan hasil analisa mengenai permasalahan yang sudah dijelaskan agar dapat membuat alternatif penyelesaian masalah tersebut, dengan membuat rancangan basis data, tampilan layar dan keluaran dari aplikasi sistem informasi inventory dan rancangan dengan diagram konteks sebagai berikut:

1. Diagram Konteks

Berikut diagram konteks yang diusulkan untuk merancang sebuah sistem informasi inventory pada toko Rosadah.

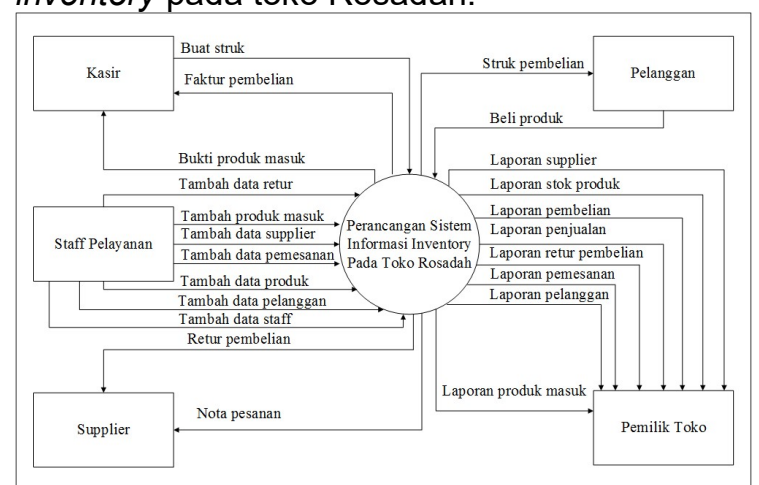

Sumber: (Muflihin \& , Harry Dhika, 2020)

Gambar 2. Diagram Konteks Aplikasi

Sistem Informasi Inventory

2. Rancangan Basis Data

a. Normalisasi

Tabel yang dihasilkan dalam pembentukkan basis data sistem informasi inventory ini merupakan tahap akhir dari proses normalisasi tabel yang telah telah melalui beberapa proses normalisasi sehingga mendapat bentuk basis data yan sudah optimal berikut basis data sistem informasi inventory tersebut.

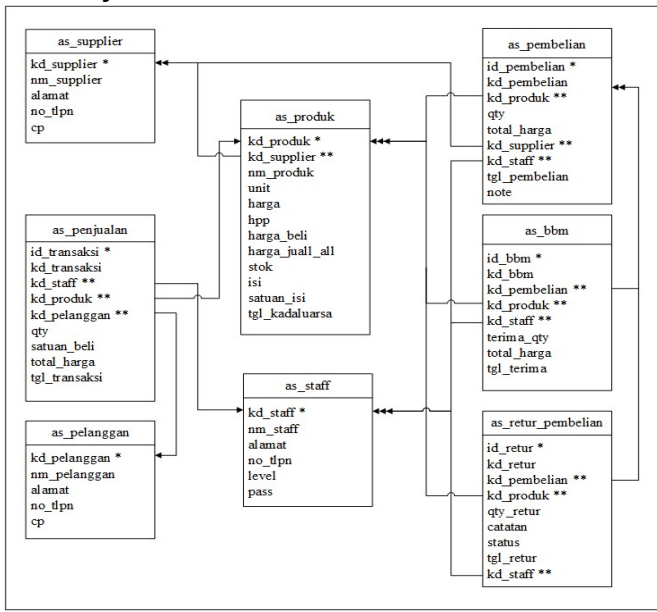

Sumber: (Muflihin \& , Harry Dhika, 2020)

Gambar 3. Tabel Hasil Normalisasi Aplikasi Sistem Informasi Inventory 
b. ERD (Entity Relationship Diagram)

ERD yang dirancang dalam membangun sistem informasi inventory ini ditunjukkan dalam Gambar 4 :

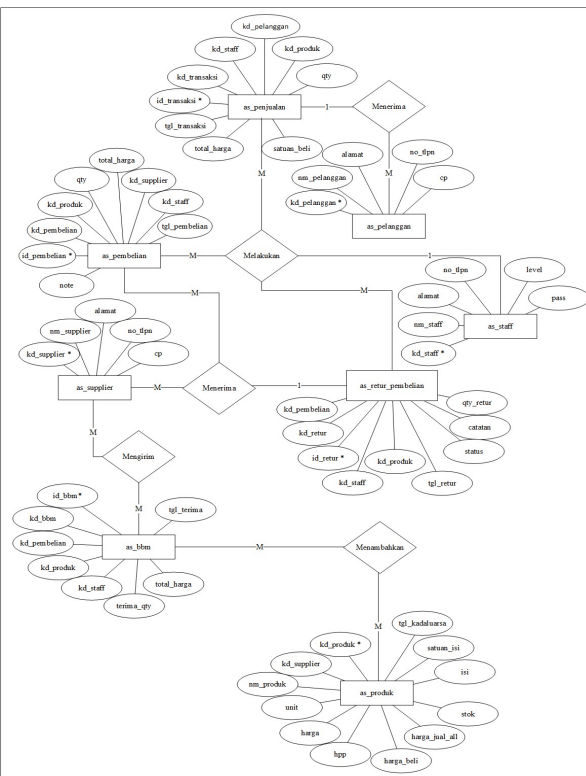

Sumber: (Muflihin \& , Harry Dhika, 2020)

Gambar 4. ERD Aplikasi Sistem Informasi Inventory

3. Desain Tampilan Layar

Berikut beberapa tampilan layar dari aplikasi sistem informasi inventory yang telah dirancang penulis berdasarkan analisa yang telah dilakukan penulis oleh penulis sebagai berikut:

a. Tampilan Menu Utama

Tampilan ini dapat ditampilkan apabila pengguna telah melakukan login ke sistem melalui form login yang sudah disediakan apabila yang login sebagai staff pelayanan maka menu yang aktif pada halaman utama dibatasi yang tersedia hanya menu selain menu penjualan dan jika yang login sebagai kasir maka akan diarahkan langsung ke menu transaksi penjualan ataupun melalui menu penjualan yang terdapat pada menu utama, menu yang tersedia untuk kasir selain penjualan yaitu menu laporan. Gambar 5 tampilan layar menu:

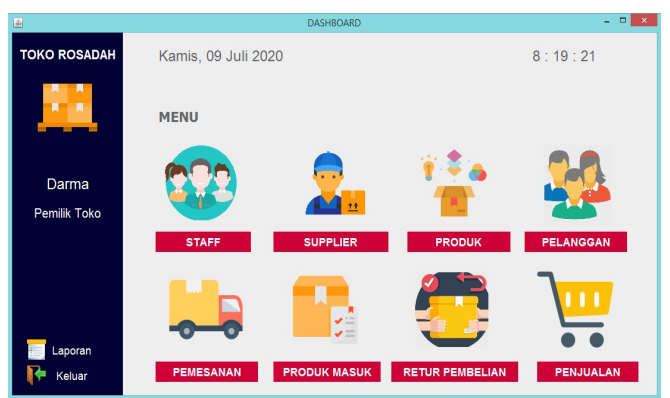

Sumber: (Muflihin \& , Harry Dhika, 2020)

Gambar 5. Tampilan Menu Utama b. Tampilan Menu Pemesanan

Selain menu utama pada gambar diatas terdapat menu pemesanan, menu ini digunakan untuk membuat surat pesanan yang dilakukan oleh toko dan dikirimkan ke supplier, menu pemesanan ini hanya dibuat oleh staff pelayanan dan selain itu untuk dapat melakukan pemesanan harus mendaftarkan data produk, data supplier, dan data staff pelayanan. Hal ini dilakukan untuk mempermudah melakukan pendataan pemesanan yang dilakukan oleh toko. Berikut tampilan layar menu pemesanan:

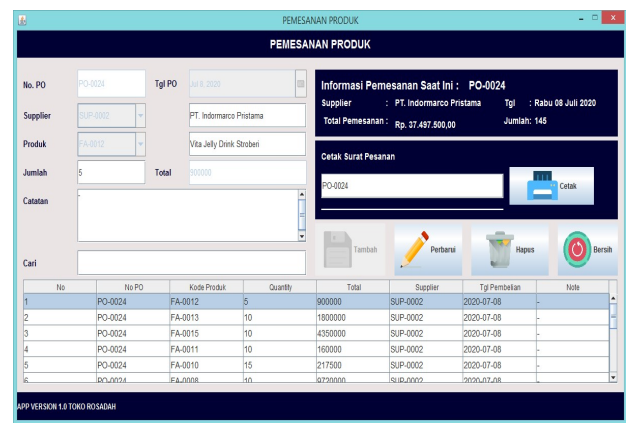

Sumber: (Muflihin \& , Harry Dhika, 2020)

Gambar 6. Tampilan Layar Menu

Pemesanan

c. Tampilan layar Menu Produk Masuk

Setelah melakukan pemesanan supplier mengirimkan produk yang telah dipesan oleh toko oleh karena itu dibutuhkan form produk masuk yang digunakan untuk mendata produk yang dikirim oleh supplier untuk mengecek apakah produk yang dikirim oleh supplier sesuai dengan pesanan, jika sudah maka untuk mengantisipasi kehilangan data pembelian ke supplier maka dibuatlah faktur pembelian dan bukti produk masuk yang berguna untuk mendata transaksi tersebut dan sebagai bukti agar kasir dapat melakukan pembayaran sesuai dengan faktur pembelian tersebut. Berikut tampilan layar menu produk masuk:

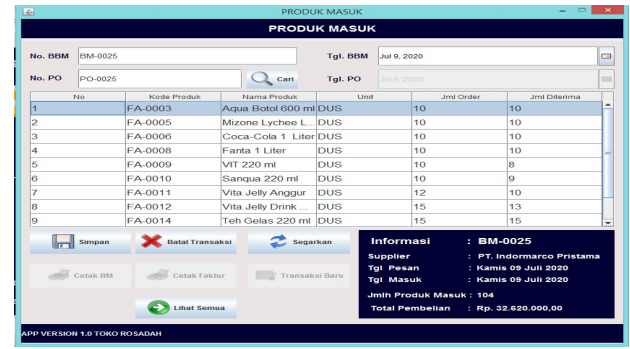

Sumber: (Muflihin \& , Harry Dhika, 2020)

Gambar 7. Tampilan Layar Menu Produk Masuk

d. Tampilan Layar Menu Retur Pembelian

Pengecekan dilakukan pada proses produk masuk ini dilakukan berdasarkan produk dan jumlah yang dikirim oleh supplier 
apabila produk tersebut dicek mendapatkan produk ada yang rusak maka dilakukan proses retur produk. Proses retur produk tersebut dilakukan pada form retur pembelian yang telah disediakan oleh program inventory ini, pendataan retur pembelian ini berguna untuk mendata produk-produk yang diretur dan digunakan untuk mencetak surat retur yang akan dikirim ke supplier.

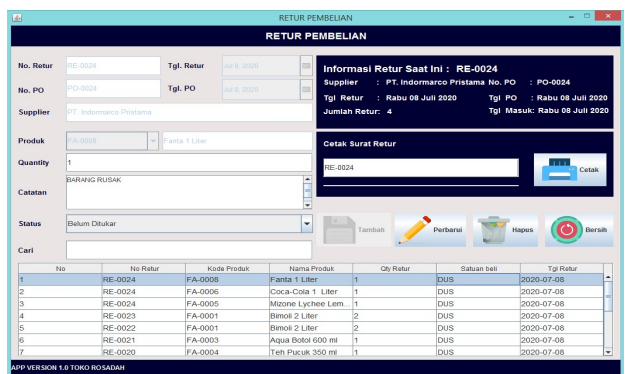

Sumber: (Muflihin \& , Harry Dhika, 2020)

Gambar 8. Tampilan Layar Menu Retur Pembelian Pemesanan

e. Tampilan Menu Penjualan

Pendataan retur ini dilakukan agar dapat mengontrol produk yang diretur dan sebagai penentuan kualitas produk supplier tersebut. Jika produk sudah lolos dalam pengecekan maka produk tersebut dapat dijual kepada pelanggan toko, transaksi penjualan ini dilakukan pada menu penjualan. Produk dapat dibeli oleh pelanggan yang sudah terdaftar pada toko yang melakukan pemesanan kepada toko via telepon ataupun media komunikasi lainnya dan dapat melakukan pembelian langsung ditoko. Berikut tampilan menu penjualan:

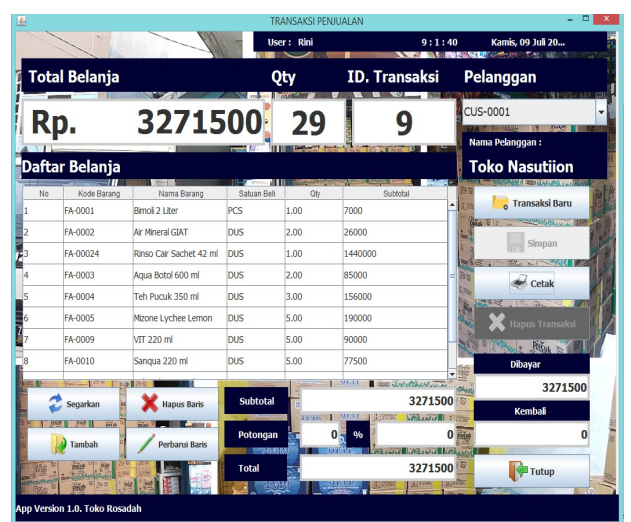

Sumber: (Muflihin \& , Harry Dhika, 2020)

Gambar 9. Tampilan Layar Menu Penjualan

f. Tampilan Menu Laporan

Pada menu laporan terdapat fitur untuk mencetak laporan penjualan, laporan pembelian, laporan pemesanan, laporan supplier, laporan stok produk, laporan produk masuk, laporan pelanggan dan laporan retur pembelian.

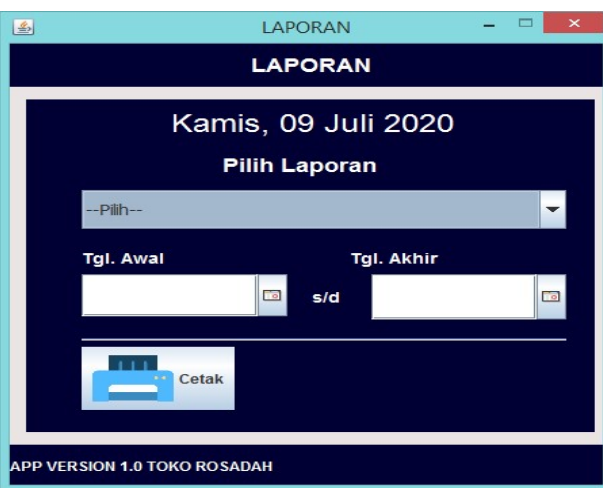

Sumber: (Muflihin \& , Harry Dhika, 2020)

Gambar 10. Tampilan Layar Menu Penjualan

4. Desain Tampilan Keluaran

Berikut ini beberapa keluaran dari aplikasi sistem informasi inventory yang telah dirancang:

a. Nota Pesanan

Keluaran nota pesanan yang berisi data pesanan yang dibuat oleh staff pelayanan yang akan dikirim ke supplier. Berikut tampilan keluarannya:

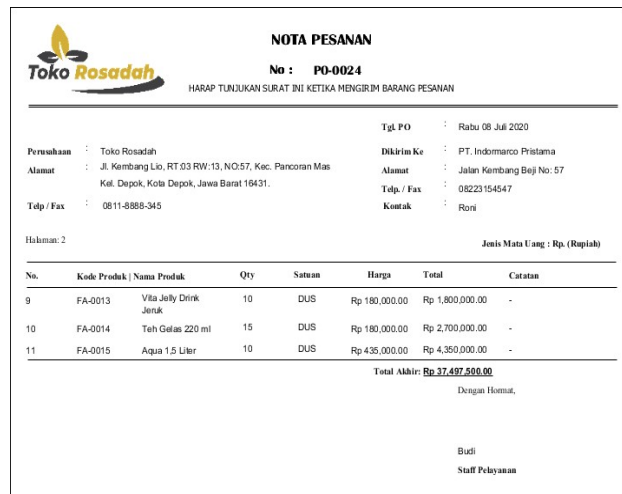

Sumber: (Muflihin \& , Harry Dhika, 2020)

Gambar 11. Tampilan Keluaran Nota Pesanan

b. Laporan Pembelian

Keluaran laporan pembelian yang berisi data pembelian yang telah dilakukan oleh toko dengan memilih rentang waktu tertentu. Berikut tampilan keluarannya:

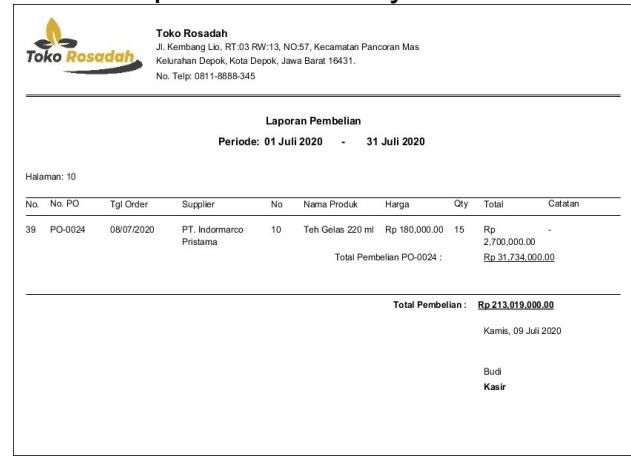

Sumber: (Muflihin \& , Harry Dhika, 2020) Gambar 12. Tampilan Keluaran Laporan Pembelian 
c. Laporan Penjualan

Keluaran laporan pembelian yang berisi data pembelian yang telah dilakukan oleh toko dengan memilih rentang waktu tertentu. Berikut tampilan keluarannya:

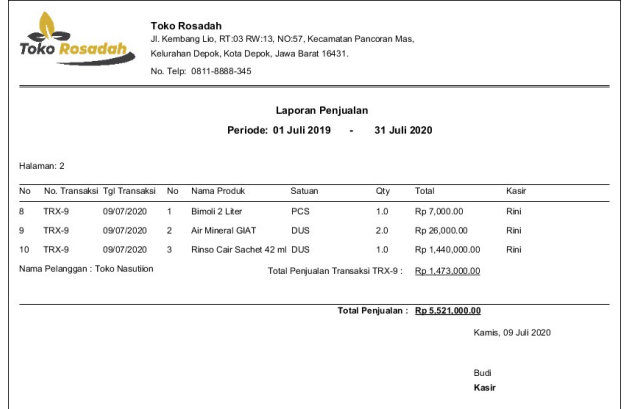

Sumber: (Muflihin \& , Harry Dhika, 2020)

Gambar 13. Tampilan Keluaran Laporan Penjualan

d. Laporan Stok Produk

Keluaran laporan stok produk berisikan data stok produk yang tersedia di toko yang dibuat oleh staff pelayanan. Berikut tampilan keluaran laporan stok produk:

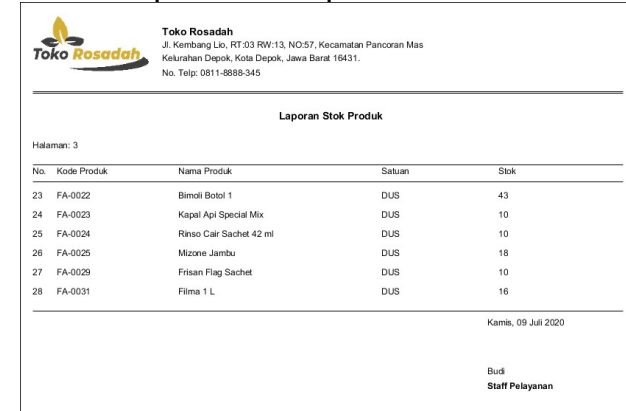

Sumber: (Muflihin \& , Harry Dhika, 2020) Gambar 14. Tampilan Keluaran Laporan Stok

\section{KESIMPULAN}

Dengan dirancangnya sistem informasi yang sudah terkomputerisasi ini diharapkan dapat membantu pihak-pihak yang terkait dalam melakukan kegiatan transaksi seperti pemesanan, penjualan, produk masuk, retur pembelian. Aplikasi ini memiliki beberapa manfaat yaitu: dapat mengubah sistem yang ada secara manual menjadi sistem yang terkomputerisasi, dapat meningkatkan efisiensi dan efektifitas kerja dalam transaksi, selain itu juga dapat mengurangi resiko kerugian akibat kesalahan manusia dan penyimpanan dibuat menjadi satu media penyimpanan yang dapat memudahkan proses pembuatan laporan dan pencarian data. Penelitian ini juga memiliki kelebihan yaitu: penelitian ini menggunakan model pengembangan sistem waterfall yang cocok untuk dalam proses perancangan aplikasi sesuai dengan kebutuhan/requirement pengguna sistem sehingga dapat mengurangi pemborosan sistem, selain itu penelitian ini memiliki kekurangan yaitu: aplikasi yang telah dirancang masih berbasis desktop belum secara daring atau online dan perlu penambahan fitur-fitur yang mungkin masih kurang bagi yang perlu fitur seperti retur penjualan, arus kas keuangan dan lainnya oleh sebab itu diharapkan dapat penelitian ini selanjutnya dapat mengembangkan dari segi tampilan dan fitur pada aplikasi sistem informasi inventory ini.

\section{REFERENSI}

Agus Heryanto, Hilmi Fuad, D. D. (2014). Rancang Bangun Sistem Informasi Inventory Barang Berbasis Web Studi Kasus di PT. Infinetworks Global Jakarta. Sisfotek Global.

Agusvianto, H. (2017). Sistem Informasi Inventori Gudang Untuk Mengontrol Persediaan Barang Pada Gudang Studi Kasus: PT.Alaisys Sidoarjo. Journal of Information Engineering and Educational Technology. https://doi.org/10.26740/jieet.v1n1.p40-46

Ardhy, F. (2017). Sistem Informasi Inventory Control Logistik Berbasis Client Server PT. Keong Nusantara Abadi. Https://Dcckotabumi.Ac.Id/Ojs/Index.Php, 5 . https://dcckotabumi.ac.id/ojs/index.php/jik/ article/view/73

Arif, M. (2016). Bahan Ajar Rancangan Teknik Industri (1st ed.). Deepublish.

Efendy, Z. (2018). Normalisasi Dalam Desain Database. Jurnal CorellT.

Febriani, O., \& Putra, A. (2013). Sistem Informasi Monitoring Inventori Barang Pada Balai Riset Standarisasi Industri Bandar Lampung. Jurnal Informatika Darmajaya. https://doi.org/10.30873/ji.v13i1.130

Indrajani. (2011). Perancangan Basis Data (1st ed.). PT. Elex Media Komputindo.

Kurniawanto, R. (2015). Sistem Informasi Inventory Berbasis Web pada PT SBI Graha Surapati Core. In Nhk技研. https://doi.org/10.1145/3132847.3132886

Maniah., \& Hamidin, D. (2017). Analisis dan Perancangan Sistem Informasi Pembahasan Secara Praktis Dengan Contoh Kasus (1st ed.). Deepublish.

Marina, A., Wahjono, S. I., Syaban, M., \& Suarni, A. (2017). Sistem Informasi Akuntansi: Teori dan Praktikal (1st ed.). UMSurabaya

Muflihin, H. H., \& , Harry Dhika, S. H. (2020). 
Perancangan Sistem Informasi Inventory Pada Toko Rosadah.

Munthe, I. R. (2019). Perancangan Sistem Informasi Pengarsipan Data Penduduk Pada Kantor Camat Bilah Hulu Kabupaten Labuhan Batu Dengan Metode System Develovment Life Cycle (Sdlc). Jurnal Informatika, 5(1), 22-31. https://doi.org/10.36987/informatika.v5i1.6 66

Noor, J. (2011). Metodologi Penelitian: Skripsi, Tesis, dan Karya IImiah Edisi Pertama (1st ed.). PT. Fajar Interpratama Mandiri.

Nugraha, W., Syarif, MuhamadNugraha, W., Syarif, M., \& Dharmawan, W. S. (2018). P. M. S. W. D. S. I. I. B. B. D. J. (Jurnal S. I. M. https://doi. org/10. 32767/jusim. v3i1. 24., \& Dharmawan, W. S. (2018). Penerapan Metode SDLC Waterfall Dalam Sistem Informasi Inventori Barang Berbasis Desktop. JUSIM (Jurnal Sistem Informasi https://doi.org/10.32767/jusim.v3i1.246

Nugroho, P. A. (2018). Sistem Informasi Inventory Untuk Mengefektifkan Pencarian Barang Pada PT. Sari Husada. Http://Jurnalpradita.Com/Index.Php, 3. http://jurnalpradita.com/index.php/jii/article /view/60/46

Nur Laila, W. (2011). SISTEM INFORMASI PENGOLAHAN DATA INVENTORY PADA TOKO BUKU STUDI CV. ANEKA ILMU SEMARANG. Jurnal Teknik Elektro, Vol. 3 No. https://journal.unnes.ac.id/nju/index.php/jt e/article/view/1560/1736

Rahmadi, L., \& Yusmiarti, K. (2016). Perancangan Sistem Informasi Inventory Di Amik Lembah Dempo Pagaralam. Seminar Nasional Teknologi Informasi Dan Multimedia.

Ramadhani, T. S., Suryadi, S., \& Irmayani, D. (2019). Sistem Informasi Stok Gudang Pada Platinum Hotel Berbasis Web.
Jurnal

Informatika.

https://doi.org/10.36987/informatika.v6i2.7 45

Rena, M. (2014). Perancangan Sistem Informasi Manajemen Perawatan Mesin Berbasis Group Technology (Studi Kasus: PT. Adi Putro Wirasejati Malang). Http://Jrmsi.Studentjournal.Ub.Ac.Id/, 2. http://jrmsi.studentjournal.ub.ac.id/index.p hp/jrmsi/article/view/112

Sasmito, G. W. (2017). Penerapan Metode Waterfall Pada Desain Sistem Informasi Geografis Industri Kabupaten Tegal. Jurusan Teknik Informatika, Vol. 2, No. https://media.neliti.com/media/publications /101354-ID-penerapan-metode-waterfallpada-desain-s.pdf

Siyoto, S., \& Sodik, A. (2015). Dasar Metodologi Penelitian (Ayup (ed.); 1st ed.). Literasi Media Publishing.

Tarjo. (2019). Metode Penelitian Sistem 3X Baca (1st ed.). Deepublish.

Timotius, K. H. (2017). Pengantar Metodologi Penelitian: Pendekatan Manajemen Pengetahuan untuk Perkembangan Pengetahuan (1st ed.). ANDI.

Wahana, A., \& Riswaya, A. R. (2014). Perancangan Aplikasi Pengolahan Data Report Penjualan. Jurnal Computech \& Bisnis.

Wardana, M. A. (2018). Jurnal IImiah Sistem Informasi dan Teknik Informatika "JISTI" Sistem Informasi Inventory Barang Kantor PT. POS (PERSERO) Kabupaten Soppeng. In Jurnal IImiah Sistem Informasi dan Teknik Informatika "JISTI."

Widiawati. (2020). Metodologi Penelitian Komunikasi Dan Penyiaran Islam (1st ed.). Edu Publisher.

Yurindra. (2017). Software Engineering (1st ed.). Deepublish. 